Bond University

Research Repository

\title{
From hard bed to luxury home: impacts of reusing HM Prison Pentridge on property values
}

Shehata, Waled; Abu Arqoub, Muath; Langston, Craig Ashley; Elkheshien, Rasha; Sarvimaki, Marja

Published in:

Journal of Housing and the Built Environment

DOI:

10.1007/s10901-020-09766-0

Licence:

Other

Link to output in Bond University research repository.

Recommended citation(APA):

Shehata, W., Abu Arqoub, M., Langston, C. A., Elkheshien, R., \& Sarvimaki, M. (2021). From hard bed to luxury home: impacts of reusing HM Prison Pentridge on property values. Journal of Housing and the Built

Environment, 36(2), 627-643. https://doi.org/10.1007/s10901-020-09766-0

\section{General rights}

Copyright and moral rights for the publications made accessible in the public portal are retained by the authors and/or other copyright owners and it is a condition of accessing publications that users recognise and abide by the legal requirements associated with these rights.

For more information, or if you believe that this document breaches copyright, please contact the Bond University research repository coordinator. 


\title{
From hard bed to luxury home: Impacts of reusing HM Prison Pentridge on property values
}

\author{
Waled Shehata ${ }^{1}$, Muath Abu Arqoub ${ }^{1}$, Craig Langston ${ }^{1}$, Rasha Elkheshien$^{2}$, and Marja Sarvimäki ${ }^{1}$
}

${ }^{1}$ Faculty of Society and Design, Bond University, Gold Coast, Australia

${ }^{2}$ Independant researcher

Waled Shehata

ORCID iD: https://orcid.org/0000-0002-0065-5598

$+61431160996$

waled.shehata@student.bond.edu.au

\section{Acknowledgements}

This article is supported by a Bond University Postgraduate Research Award. Travel grant and data collection were funded by Australian Government Research Training Program Scholarship. 


\section{From hard bed to luxury home: Impacts of reusing HM Prison Pentridge on property values}

This paper uses statistical analyses to understand the effect of proximity of old prisons on property prices. The study employed semi-log hedonic regression models; a quantitative research method applied to assess the impact of proximity to heritage gaols on property prices for a case study of HM Prison Pentridge in the time range between 2015-2019. Results demonstrated that the former Pentridge has a variable effect on properties lying in and around its current heritage borders. Pentridge shows a diminution effect on prices of residential properties on its land currently being developed to a mixed-use precinct, as well as its intimate surrounding residences. Inversely, Pentridge shows a positive price-effect on properties lying at distances between $400 \mathrm{~m}$ to the maximum study range of $1400 \mathrm{~m}$ in the case of 'houses', and between $600 \mathrm{~m}$ to the range of $1000 \mathrm{~m}$ in the case of 'units'. Findings of this research suggest that prices of properties with direct visual access to Pentridge's structures are negatively affected. Results also suggest that Pentridge's current redevelopment project may have contributed positively to property prices lying outside the direct visibility zone. To be able to further validate these interpretations, similar research may consider other variables influencing property valuation, such as direct visibility of the gaol as well as interviews that assess the 'attractability' of Pentridge's redevelopment. Future studies may examine the rate of change in property price along time for each distance band from the gaol borders. Future research may also consider duplicating the methodology to assess the comfortability towards gaols converted to museums, as well as gaols that are still in operation. The originality of this research emerges from the distinct lack of quantitative evidence in the current literature. Most research has investigated uncomfortable heritage focusing on qualitative assessments of memory, stigma, commemoration, and shame, with limited scholarly attention paid towards property depreciation effects as a result of Australia's prison history, nor increasing effects due to gaols' reuse and redevelopment. Decision-makers and stakeholders of equivalent dark heritage reuse projects will find this research useful in understanding potential impacts on surrounding property prices. Property valuers and real estate companies operating in Coburg - a suburb of Melbourne, Australia - may use the related tables and figures in guiding their business for the coming years.

\section{Keywords}

adaptive reuse, Coburg, gaols, HM Prison Pentridge, property value, proximity, Uncomfortable heritage 


\section{Introduction}

In the $20^{\text {th }}$ Century and after years of operation, most of the Australian heritage-listed gaols (Australian English for jails) were decommissioned and closed, like other old and valuable structures for various reasons (Langston, 2011). Despite representing uncomfortable memories, many of them were reused to new functions that can be described as far from commemorating their uncomfortable history (Shehata $e t$ al., 2018). For instance, Darlinghurst Gaol in the heart of Sydney was transformed into an art school, while Bendigo Gaol was adaptively reused into a theatre and part of a local high school. HM Prison Pentridge in Melbourne is one of these cases, as it has been undergoing transformation into a mixed-use and residential development shortly after its closure in 1997. Due to the site's uncomfortable memories, property prices in and around old gaols might be affected, an assumption that has invited this analytical scrutiny.

\section{Proximity}

Studies of housing and built environment tend to link property values to multiple external parameters combined, among which is the 'location' (Whipple, 2006). On the one hand, proximity to scenic views (Mothorpe and Wyman, 2017; Nicholls and Crompton, 2018), heritage houses (Narwold, 2008), services such as nodes of public transport (Diao et al., 2017) and open space and parks (McCord et al., 2014) are proven to cause increase in neighbouring property prices. On the other hand, proximity to hazards or risks suggest reduction of property prices such as high voltage overhead transmission lines, or HVOTLs (Bond, 2013; Wyman and Mothorpe, 2018), pollutants (Endah, 2013; Simons and Saginor, 2006; Simons et al., 2015), stigmatised properties (Chapman et al., 2019), haunted houses (Bhattacharya et al., 2019), and gaols (Broome, 1988). Living in proximity to gaols ignites numerous uncomfortable thoughts in the minds of communities (Galford and Peek, 2015) that is active through different mechanisms such as direct visualisations (Mann, 2017) or uncomfortable memories (Wilson, 2005) or both. As confirmed by Dent and Sims (2013) and Pope (2008), whether proximity to a negative influence - such as old gaols - 
poses actual threats to the residents, high emotive responses (i.e. senses of discomfort, stigma, etc.) could be easily generated towards them and maybe enough to cause fluctuation to property prices. For instance, Galford and Peek (2015) recognised the concept of 'shame' to exist among the local community around contemporary housing precincts originally an old gaol and a psychiatric asylum, leading to struggles of securing tenants. However, because these emotions are subjective, non-linear, contested, and controversial (Chappells and Shove, 2005; Shin, 2016), the resultant patterns of price fluctuations are not necessarily negative - thus we need to break away from prejudices. According to Powell and Sanguinetti (2010), the effect of the same subjective variable on property prices might reveal opposing impacts in different contexts. Supporting that claim and unlike the popular belief that water frontage or view has a significant positive effect on property prices, Hui et al. (2012) concluded that the availability of sea-views is not considered a positive attribute to the transaction prices of high-storey flats in Hong Kong. Likewise, when discussing topics of dark heritage, it would be subjective to conclude decisive patterns of effect of proximity to gaols on property prices with no precedent studies. Studying the impact of the proximity of former Australian gaols on property values has been far from complete.

The aim of this paper is to provide an inaugural understanding of the price impact of proximity to an old gaol on surrounding residential property. This research selected HM Prison Pentridge as its case study. Pentridge provides a rich case study not only because it lays within 6 kilometres north of the CBD of Melbourne, but also because its reuse involves residential developments taking place within its boundaries, between its former wards, and even inside its old buildings. Following the local government plans of urban consolidation of Melbourne's urban fringes (Buxton and Scheurer, 2005), Pentridge, the locus of a century-and-a-half of notoriously brutal incarceration, was sold to developers who are currently adapting it into a dozen or so hectares of modern house-and-land packages in a mixed-use development. Pentridge has turned from a place where inmates would have paid all their possessions to flee, to a place where people spend hundreds of thousands of dollars to live in and around its walls. Many heritage Australian gaols similarly lay within the fringes of urban centres and are underused (Shehata et al., 2018), 
making them a focus of redevelopment plans along with their surroundings. Using more accurate measures to assess the impact of proximity to former gaols on property prices, better assistance may be provided to decision-makers, heritage consultants, urban planners, developers, property valuers, real estate agents, and property taxation authorities. This research is one among a series of investigations focusing on the adaptive reuse of Australia's heritage gaols - see Shehata et al. (2018).

\section{HM Prison Pentridge in Coburg}

Her Majesty's Prison Pentridge (HM Prison Pentridge) was established in 1850, eight kilometres north of Melbourne in small farmland named Pentridge (later renamed Coburg) and served as Victoria's central prison until its closure in 1997. Numerous books and publications were written about its establishment, its life in operation and after. For instance, this included its history (Lynn and Armstrong, 1996; Osborne, 2015), prison life and events (Osborne, 2015), its memory in the lives of its inmates (Mann, 2017), burials of executed prisoners (Smith, 2011), rehabilitation logic of its prisoners (Edney, 2006), the gaol in the eyes of the local community of Coburg (Broome, 1988), and its historical interpretation (Wilson, 2005). The following section focuses on Pentridge's effect on its neighbourhood in literature since its early days of operation.

\subsection{In operation}

Pentridge is a complex of locally quarried ashlar bluestone structures comprising several discrete subprisons 'divisions', which at times housed upwards of one thousand prisoners (Wilson, 2005). These divisions stood enclosed within a six-metre-high boundary wall - also of bluestone - topped with neogothic embattlements and towers that, for many, constituted the gaol's defining image (Figure 1). During its years in operation, Pentridge exerted a dominating influence, not only visually, but socially, on the surrounding suburban community, earning for itself the ironical sobriquet 'Bluestone College' (Wilson, 2005). Similar to other prisons worldwide (Pratt, 2003), Pentridge was a powerful symbol of evil and grimness near civic symbols of good and is reported a few times in Broome (1988) to have negatively 
affected the property and land prices in its neighbourhood. Standing beside three churches, three schools and the chambers of local government did not pardon lower property prices. Farmers in North of Melbourne reported Pentridge twice to had caused property values reduction in 1859 and 1860, followed by a third depreciation reported in 1867 (Broome, 1988). Perhaps the last documented effect was in 1945 after a campaign by the locals to remove Pentridge from Coburg, when Joseph Ackeroyd, the InspectorGeneral of Prisons, described this campaign to be based on selfish concerns of the locals to avoid reduction of land values (Broome, 1988).

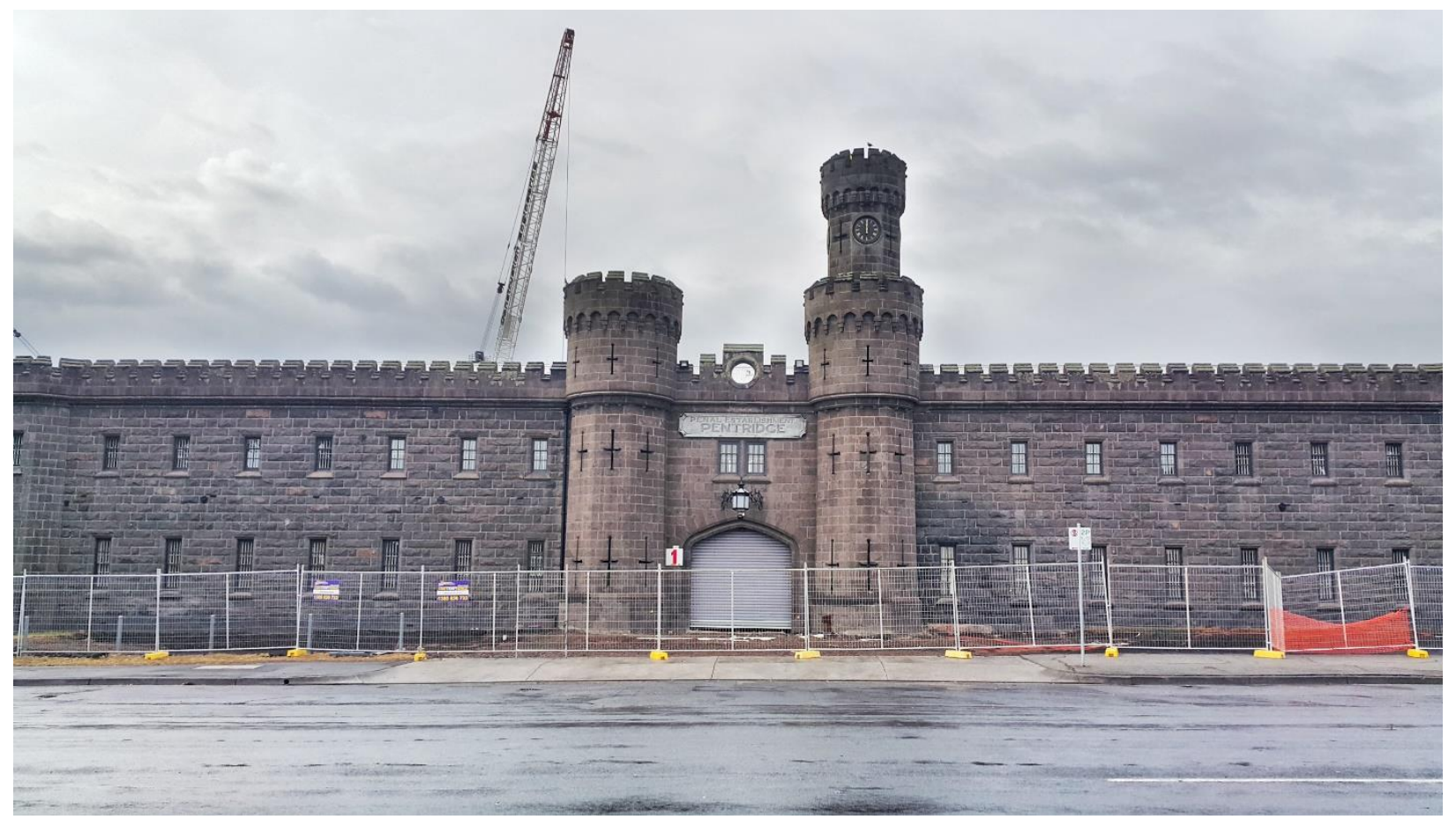

Figure 1. Pentridge's neo-gothic architecture. Image by authors.

\subsection{It's after-life}

On 28 November 1997, the entire prison was officially closed (Moreland City Council, n.d.). The decision to sell the prison complex to private interests came quickly after it was decommissioned (Mann, 2017; Osborne, 2015; Wilson, 2005). In 1999, the government sold off the sixty-acre site of Pentridge to a development consortium that quickly demolished some of its buildings and packed residential developments (Figure 2), as well as other mixed typologies, into the site (Figure 3). Some original 
structures, cell blocks, and the prison's iconic castellated façade are preserved and are being adaptively reused into a commercial mixed-use precinct including boutique hotels, wine bars, cafés, and offices (Mann, 2017; Shayher Properties, 2014; Wilson, 2004). No longer is it Pentridge Prison, but Pentridge’ Piazza', 'Heritage', or 'Village' (Mann, 2017).

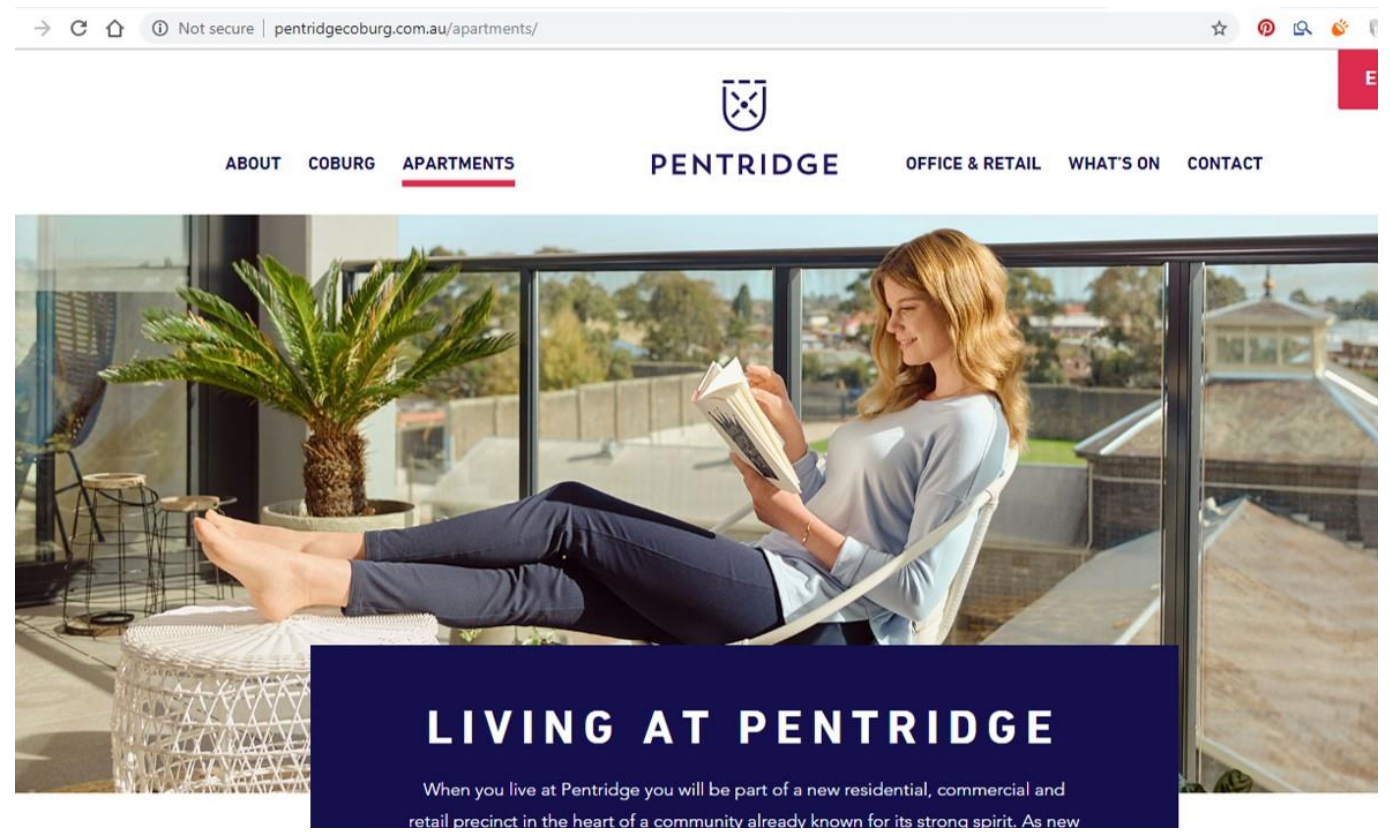

Figure 2. Screenshot of the developer's website promoting comfortable residential developments with Pentridge Prison in the background. Source: Shayher Properties Pty Ltd (n.d.).

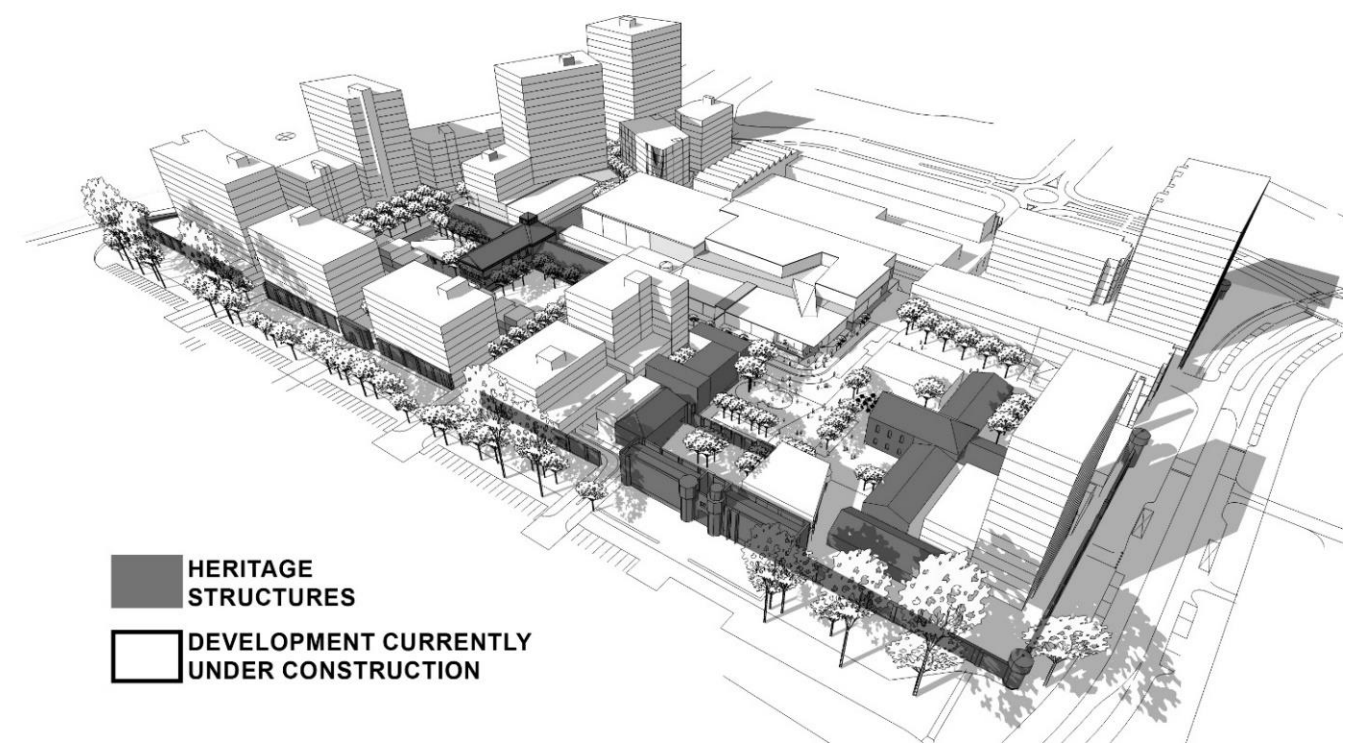

Figure 3. Vision for Pentridge currently under construction. Adapted after: Shayher Properties Pty Ltd (n.d.). 


\section{Property prices in Coburg}

Unlike the general agreement of the diminution of price effect exerted by proximity to HVOTLs on the surrounding property prices, the former HM Prison Pentridge and its current redevelopment may exert a more complex price influencer. The following section presents both arguments, which hypothesise how property prices around Pentridge may be influenced either positively or negatively by its history and its current redevelopment.

\subsection{Positively}

Ruins of heritage buildings usually add a touch of roughness to otherwise modern and commercial cityscapes. According to Sandler (2011), crumbling or grimy walls make the bustling tangle of streets more exciting for the tourists and convert urban dilapidation into 'ultra-chic'. Preservation and maintenance of historic structures within a particular area often result in neighbourhoods that are said to have 'character' (Narwold, 2008). Pentridge's bluestone walls and structures add this picturesque element to Coburg (Mann, 2017), which may appear to be enough to steer the perception of the community away from its dark history.

For the developers who are deploying the prison's architecture in economic rationalism, they push a narrative that attempts to exploit the history of the gaol, while in the same breath, hiding the darkness of that history (Mann, 2017). Changing the name from 'Her Majesty's Prison' Pentridge to 'The Pentridge Village' or 'The Pentridge Piazza' indicate the keen-ship of profit return based on an increase of land values, hence also the property values (Mann, 2017; Wilson, 2005). At Pentridge, developers are attempting to dictate the way the local community remembers the gaol and how would they connect with its history (Mann, 2017). According to contemporary European urban planning policies and while the developers are creating mixed-use development on Pentridge, the new jobs, restaurants, bars and other facilities near residential properties are generally claimed to result in rising property values (Koster and Rouwendal, 2012). 
Nonetheless, the proximity of Coburg to Melbourne's CBD is another factor which may justify the frenzied rate of development around Pentridge. With the rise in property values near the CBD, turning dark heritage sites like Pentridge to residential developments sounds economically pragmatic (Wilson, 2005; Shehata et al., 2018). Even further, some evidence suggests that Pentridge's closure might have contributed to the increase of financial revenues of the developments in and around it (Figure 4). Until 1989, Coburg's 'house' prices were among the twenty lowest median-priced Melbourne suburbs (Swinburne Institute for Social Research, 2000) with a score of AUD 120,000, slightly less than of the whole of Melbourne AUD 135,000 (Abelson and Chung, 2005). With not enough data about house price medians of Coburg between 1990 and 1999, Coburg's house median sales prices showed increase somewhere in the late 1990s not only to exceed Melbourne's median house prices in 2000 onwards (Abelson and Chung, 2005) but also to significantly surpass the median of houses prices of Victoria (State Government of Victoria, 2019). 'Unit' prices, on the other hand, did not show significant pattern since the year 2000 when compared to medians of Melbourne and Victoria, but consistently shows lower rates than Melbourne's since 2010 and until 2017 (Figure 5). Despite that, these figures assume that Pentridge's decommissioning in 1997 might have contributed to the recovery of 'house' prices in Coburg from 1999 onwards, but it does not provide affirmative evidence of the impact of the former HM Prison Pentridge on the neighbouring residential uses prices. 


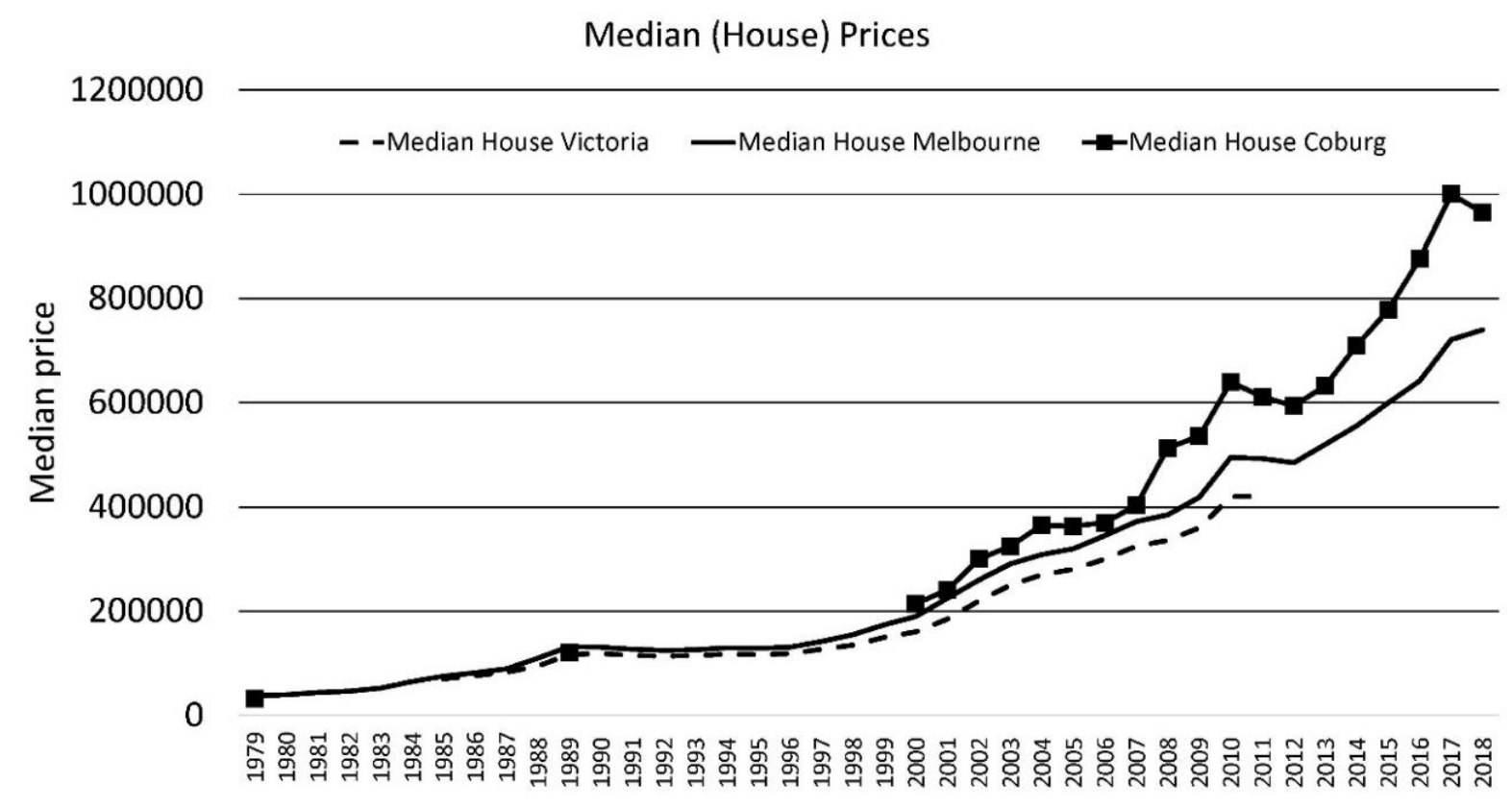

Figure 4. Comparison of Median 'House' Prices of Victoria, Melbourne, and Coburg. Graph by authors based on data in Abelson and Chung (2005); State Government of Victoria (2019); and Swinburne Institute for Social Research (2000).

\section{Median (Unit) Prices}

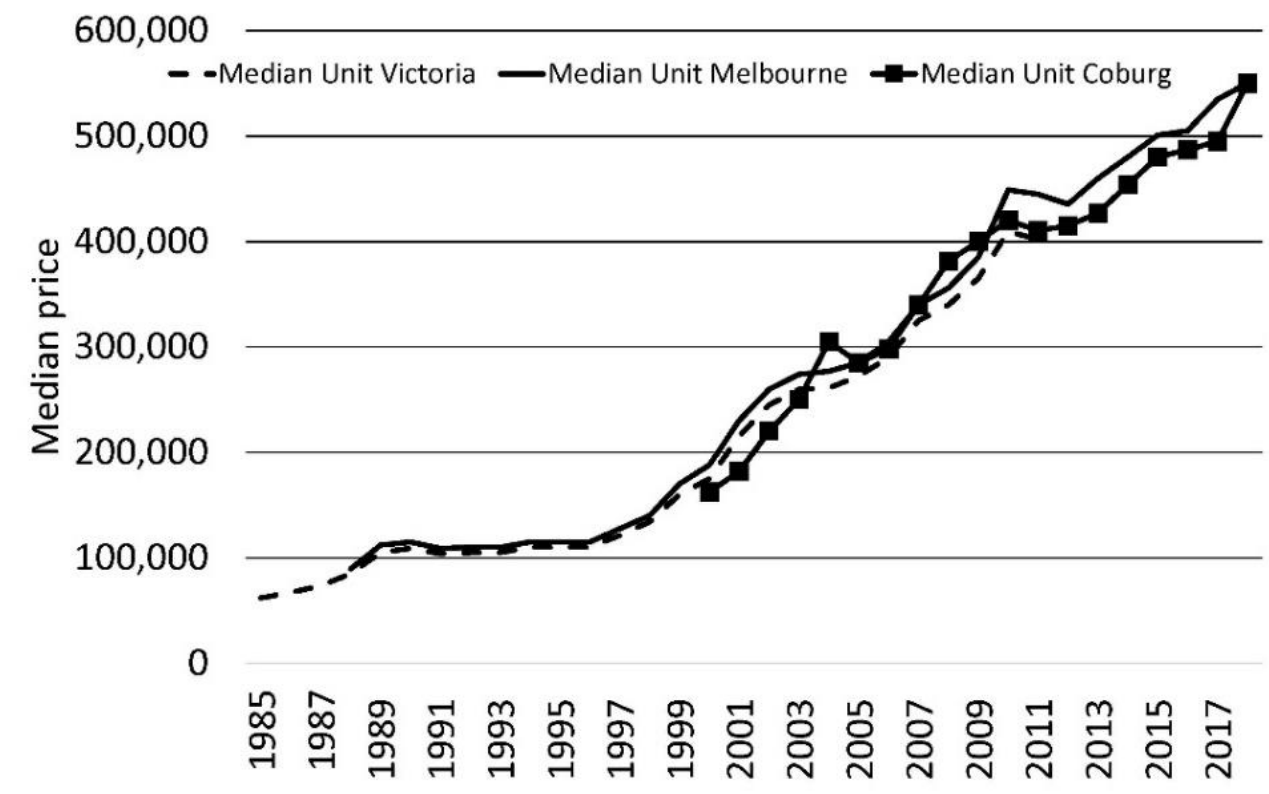

Figure 5. Comparison of Median 'Unit' Prices of Victoria, Melbourne and Coburg. Graph by authors based on data in Abelson and Chung (2005); State Government of Victoria (2019); and Swinburne Institute for Social Research (2000). 


\subsection{Negatively}

Evidence from literature confirms that Pentridge would remain a negative influence on the surrounding community. Even before Pentridge's closure, Broome (1988) forecasted that Pentridge would continue to provide a dramatic juxtaposition in the heart of Coburg for hundreds of years after its decommissioning. Also in his book, Mann (2017) confirms that the knowledge of what happened behind Pentridge's walls the horror, the hell, the hundreds of suicides, violent murders, state-sanctioned executions, and guard brutality even in its women's sections in the 1980s and 1990s (Carlton, 2018) - infuse these new residential developments taking place on its grounds with blunt dread. Buying Pentridge, building homes in it, and then pretending it's not a prison to be able to sell those homes cannot defeat its darkness.

“...[Pentridge's] history cannot be forgotten or swept away. No matter what its new owners do to lend Pentridge its sparkling new veneer, the dark, menacing structures at its heart remind us of how its inmates suffered in secrecy and silence behind those bluestone walls." Osborne (2015, p. 344).

Wilson (2005) researched Pentridge by canvassing the feelings and opinions of Pentridge's neighbours regarding the former gaol after decommissioning. A very significant degree of ambivalence toward the place was generally encountered. These uncertain and contradictory readings of the current situation necessitated more decisive research. The next section describes the data utilised in this analysis, followed by an explanation of the methodology employed. The results are then examined with some concluding remarks.

\section{Methodology}

The Hedonic Pricing Model (HPM) is a multiple regression statistical analysis and is the methodology employed to measure the proximity effect of the uncomfortable heritage of Pentridge on residential properties within its boundaries and in its neighbourhood. Analysing actual house sales transaction data, HPM is a valid quantitative methodology that is abundantly used in the literature assessing value diminution from external factors. This methodology was developed by Priestley and Ignelzi (1989) and applied; for instance - by Bond (2013), Callanan (2013), Jackson and Pitts (2010), Kiel and Boyle (2001), 
Simons and Saginor (2006), Wyman et al. (2013) and Wyman and Mothorpe (2018) - dominantly to assess the effect of proximity of HVOTLs on residential property values in numerous case study areas. In other implications, Narwold (2008) used the same methodology to measure the proximity effect of heritage-listed houses on the neighbouring home values, while McElveen et al. (2017) used it to examine the impact of a natural gas pipeline on the sales prices of nearby homes in Florida. Similarly, Sah et al. (2016) used the hedonic price model to measure the school proximity effects on nearby residential property prices. This research uses the same methodology but considering the former HM Prison Pentridge as a potential factor in properties' values.

\section{Study range}

Pentridge's eastern edge throughout its history is not constant (Figure 6). In 1857, its eastern boundaries extended to the Merri Creek, and in 1954, its farmland was reduced to half when the prison's walls retreated to what is currently Oriley Road (Lynn and Armstrong, 1996). Pentridge's current borders are even smaller and are set by its extent of registration as listed on the Victorian Heritage Register (as registered place H1551 File number: 602848 [1-4]). To examine the effect of the gaol in its current state, the most recent definition of Pentridge is adopted. Pentridge's heritage border was drawn on its exact coordinates using geographical information system (GIS) techniques. A land parcel map of Coburg's properties (postcode 3058) was obtained from the open-source dataset provided by the Department of Environment, Land, Water \& Planning in Victoria (Victoria State Government, 2019). Using GIS techniques, the direct distance between the nearest corner of each land parcel to the boundary of the heritage registration was measured. Land parcels that either partially or entirely inside the gaol's heritage borders, or just touching it, were considered as 0 metres distance. Parcels that touch the gaol's current border lie exclusively on lands that once belonged to Pentridge on its east side, something that significantly reduces any disparity when calculating the impact of proximity on property price. 

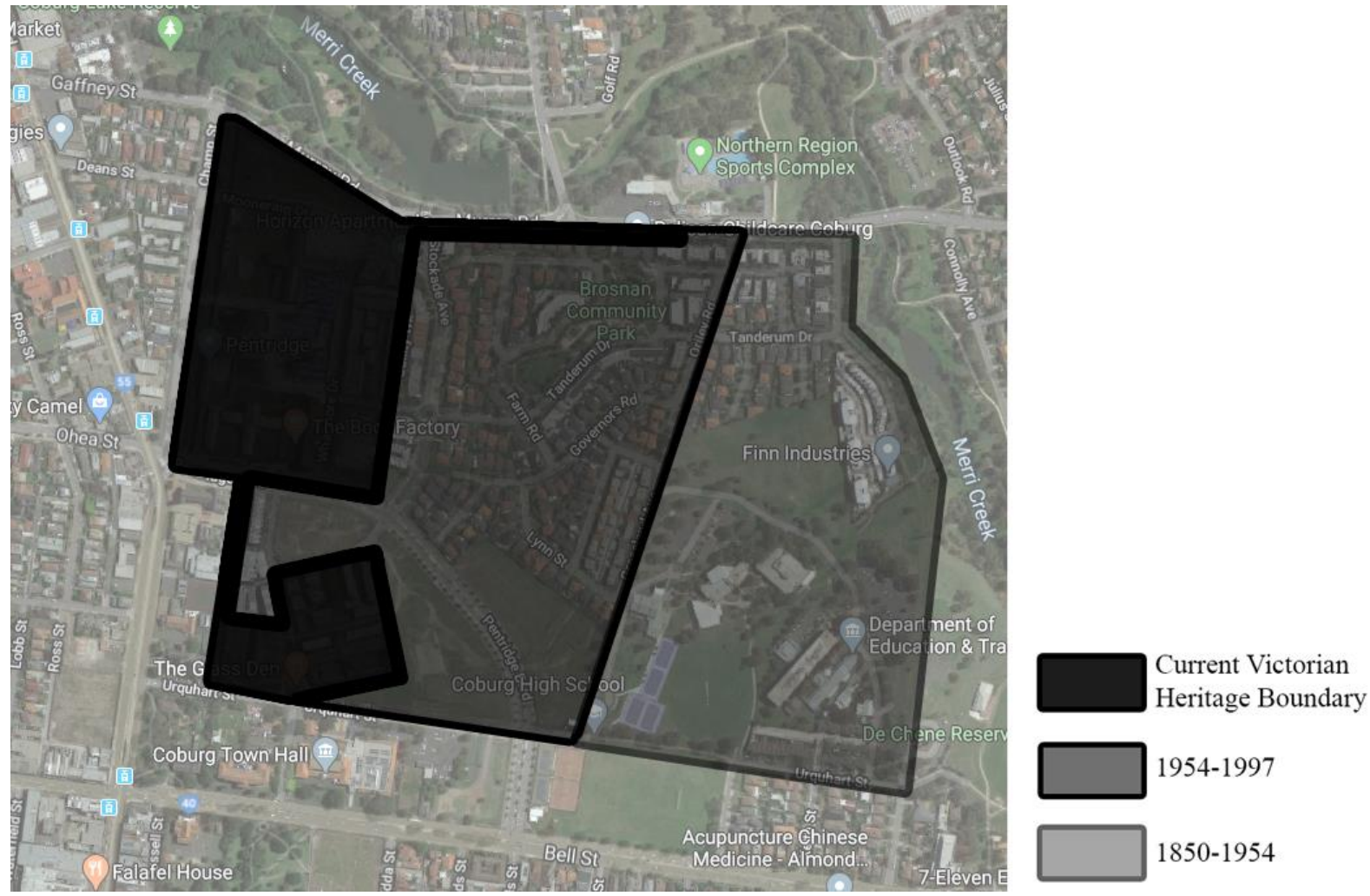

Figure 6. Tracing of HM Prison Pentridge's borders. Map by authors, based on google maps imagery and layouts provided by Kelly, Victoria. Department of Crown Lands Survey (1870); Lynn and Armstrong (1996), and Bryce Raworth Pty Ltd (2016).

This research pays attention to the impact of the proximity to Pentridge on surrounding property prices, which is effective due to direct visibility of the gaol or perception of uncomfortable memories associated with it or both. First, to set the area from which there could be any direct visual impact of the gaol, observations made on site in May 2019 established a distance of approximately 400 metres as the maximum range of which the skyline of Pentridge's bluestone walls is spotted from adjacent street levels. Secondly, and since the geographical extents of uncomfortable memories of Pentridge or other gaols are not previously discussed in literature, an additional random range of one kilometre was added to the study boundary as a precautionary buffer zone. 


\section{Variables and data}

According to Narwold (2008) and Wyman et al. (2013), the HPM tests the impact of the proximity variable while holding the influence of a variety of other characteristics of the home that affect the house price constant. These other characteristics include both internal (e.g. floor area, number of bedrooms, bathrooms, age, etc.) and external (e.g. street width, dedicated land-use zoning regulation, etc.) variables of the structure. Breaking down each property into its main characteristics allows the influence of each attribute on the total price to be determined. This approach is an accepted method of conducting a robust analysis of the impact of environmental features on house prices wherever sufficient property-specific data are available.

To achieve research validity and reliability, the set of internal and external property variables used in the study by Bond (2013) in New Zealand were mostly adopted in this study (Table 1). The resemblance between the Australian and New Zealander property markets supports the internal validity of this research. These variables are those that can be objectively determined and have significant explanatory power. Below are a few minor differences than in Bond's study:

- The Australian residential real estate market including the residential fabric of Coburg is composed of properties that are defined as residential apartments 'units' and 'houses' (RP Data Pty Ltd., 2017) unlike the research area in Bond (2013) that comprised only houses. Due to their different nature, the set of variables associated with the property valuation of 'units' in this research does not include (land size) or (property architecture).

- The variable (condition of the building) was not included in this research. Assessing the building condition is a subjective matter; besides, it is not provided in data sources.

- Numbers of bedrooms, bathrooms, and car parking spaces were three additional variables considered in this research. These data were available in the real estate transaction sources. 
Table 1. Property variables used in the analysis

\begin{tabular}{ll}
\hline Sale price & Adjusted by the Housing Price Index of Melbourne for each quarter (Australian \\
& Bureau of Statistics, 2019) \\
\hline Property features & *Land area $\left(\mathrm{m}^{2}\right)$ \\
& Floor area $\left(\mathrm{m}^{2}\right)$ \\
& Number of bedrooms \\
& Number of bathrooms \\
& Number of Lockup garages \\
& Exterior finish (brick, timber, paint, etc.) \\
& Roof finish (tiles, concrete, corrugated metal sheets, etc.) \\
& Year of construction \\
& Scenic views (yes/no) \\
& Pool (yes/no) \\
& Arterial road (State route, main street, not arterial road) \\
& *Property architecture (detached house, attached villa strata, etc.) \\
\hline Land parcel & State zoning designation (residential, commercial, etc.) based on Victoria's \\
& Planning Provisions. \\
\hline Market & Date of purchase \\
\hline Distance to Pentridge & Distance (m) \\
\hline & *Excluded from the variables for units. \\
\hline
\end{tabular}

The prime source of information on property transaction data and property variables was Corelogic (RP Data Professional), a governmental platform for Australia-wide property database. Data provided in Corelogic for each property transaction was extracted by the authors. Sales transactions were extracted for the period 31 August 1974 to 3 August 2019. The transaction data of a total amount of approximately 6,500 residential properties were downloaded - including 'houses' and 'units' - those which lie in the study zone and which have their transaction price published. Properties with incomplete information were disregarded. To eliminate substantial changes that might occur in the market price over time due to factors such as changing perceptions towards the gaol before and after its closure, or even in the third decade since its closure and start of redevelopment, the researchers adopted a five-year time frame from 2015 to 2019 (inclusive). This time interval may better represent the current perception of the local community towards the gaol, approximately two decades after its decommissioning and start of redevelopment. This time interval provided sufficient sales (490 for houses and 359 for units) within the 1,400 metres of the gaol's border, enough to make the regression equation statistically reliable and to give confidence in the results. 


\section{Results}

In order to assess the effect of different property-related features and the distance to HM Prison Pentridge on the price of 'houses' and 'units' within the prison boundaries, semi-log hedonic regression models were used. Due to the difference in variables selected for 'houses' than the ones for 'units', two separate models were developed for each. Natural logarithm of price was used as the dependent variable in both models. Variable transformation forms were applied to the continuous predictors (floor area and land size for houses, and floor area only for units) in order to choose the form that will produce the model with the best fit. The choice was based on Akaike Information Criterion (AIC), and the forms that produced the lowest values for the 'houses' price model were the natural logarithm of floor area and the square root of land size. For the 'units' model, the best fit was achieved with natural logarithm of floor area. In both models, proximity to the prison was entered as a series of dummy variables, by converting the distance into five ranges separated by equal intervals of $200 \mathrm{~m}$ starting from $0-200 \mathrm{~m}$ to $800-1000 \mathrm{~m}$, in addition to the last distance range (1000-1400m). Other property-related features were all entered as dummy variables.

Stepwise regression was used to choose the best fitting model by bi-directional elimination of variables using AIC as a selection criterion. Parameters of the final model for 'houses' pricing are presented in (Table 2). The model was able to significantly predict the 'houses' price $(\mathrm{F}=56.24, \mathrm{p}<0.001)$ and $70 \%$ of the variation in sale price was explained by the variation in the predictors $\left(\mathrm{R}^{2}=0.701\right)$. All the predictors in the model were significant $(\mathrm{p}<0.05)$ including three categories of prison proximity $-0-200 \mathrm{~m}, 200$ $400 \mathrm{~m}$ and $400-600 \mathrm{~m}$ - that all had a significant lowering effect on the price.

Similarly, for 'units', the final model was able to significantly predict the price $(F=92.615, p<0.001)$ and $84.7 \%$ of the variation in sale price was explained by the variation in the predictors $\left(\mathrm{R}^{2}=0.847\right)$. All the predictors in the model were significant $(\mathrm{p}<0.05)$. However, regarding proximity to the prison, it was found that only a distance of (200-400m) had a significant lowering effect on the price. Parameters of the final model for 'units' pricing are presented in Table 3. 
Table 2. Statistical results of the final model for 'houses'

\begin{tabular}{lcccc}
\hline Variable & Coefficients & Std. Error & $\boldsymbol{t}$-value & p-value \\
\hline Intercept & 11.323 & 0.15 & 75.287 & $<0.001$ \\
\hline Distance to Pentridge (0-200m) & -0.109 & 0.03 & -3.645 & $<0.001$ \\
\hline Distance to Pentridge (200-400m) & -0.068 & 0.025 & -2.793 & 0.005 \\
\hline Distance to Pentridge (400-600m) & -0.04 & 0.02 & -2.062 & 0.04 \\
\hline Number of Lockup garages (10) & 0.691 & 0.164 & 4.22 & $<0.001$ \\
\hline Number of Lockup garages (7) & 0.389 & 0.157 & 2.477 & 0.014 \\
\hline Floor area & 0.271 & 0.031 & 8.674 & $<0.001$ \\
\hline Property architecture (detached dwelling) & 0.162 & 0.025 & 6.581 & $<0.001$ \\
\hline State zoning designation (Activity Centre & 0.162 & 0.059 & 2.762 & 0.006 \\
Zone - Schedule 1) & 0.14 & 0.054 & 2.613 & 0.009 \\
\hline Year of construction (1890) & 0.118 & 0.02 & 5.877 & $<0.001$ \\
\hline Not arterial road & 0.104 & 0.024 & 4.32 & $<0.001$ \\
\hline Property architecture (attached dwelling) & 0.07 & 0.018 & 3.949 & $<0.001$ \\
\hline Exterior finish (timber) & $5.19 \mathrm{E}-07$ & 0 & 9.1 & $<0.001$ \\
\hline Land size & -0.066 & 0.029 & -2.279 & 0.023 \\
\hline Roof finish (concrete) & -0.074 & 0.019 & -4.02 & $<0.001$ \\
\hline Number of bathrooms (1) & -0.082 & 0.038 & -2.157 & 0.032 \\
\hline Year of construction (1960) & -0.338 & 0.157 & -2.15 & 0.032 \\
\hline Year of construction (1995) & -0.577 & 0.079 & -7.316 & $<0.001$ \\
\hline State zoning designation (Industrial-1 Zone) & -0.691 & 0.157 & -4.407 & $<0.001$ \\
\hline Year of construction (2019) & & & &
\end{tabular}

Table 3. Statistical results of the final model for 'units'

\begin{tabular}{lcccc}
\hline Variable & Coefficients & Std. Error & $\boldsymbol{t}$-value & p-value \\
\hline Intercept & 10.703 & 0.163 & 65.817 & $<0.001$ \\
\hline Year of construction (2018) & 0.578 & 0.051 & 11.392 & $<0.001$ \\
\hline Floor area & 0.388 & 0.032 & 11.99 & $<0.001$ \\
\hline Year of construction (1880) & 0.203 & 0.032 & 6.324 & $<0.001$ \\
\hline Exterior finish (Brick \& Cladding \& Stone) & 0.2 & 0.05 & 4 & $<0.001$ \\
\hline Year of construction (2016) & 0.197 & 0.031 & 6.338 & $<0.001$ \\
\hline Year of construction (2017) & 0.144 & 0.027 & 5.283 & $<0.001$ \\
\hline Roof finish (Concrete) & 0.049 & 0.023 & 2.097 & 0.037 \\
\hline Exterior finish (Cladding \& Paint) & -0.068 & 0.025 & -2.65 & 0.009 \\
\hline Year of construction (2011) & -0.074 & 0.023 & -3.19 & 0.002 \\
\hline Year of construction (2008) & -0.088 & 0.023 & -3.828 & $<0.001$ \\
\hline Exterior finish (Brick \& Timber \& Paint) & -0.118 & 0.059 & -2.007 & 0.046 \\
\hline Distance to Pentridge (200-400m) & -0.146 & 0.029 & -5.127 & $<0.001$ \\
\hline Number of bedrooms (2) & -0.149 & 0.029 & -5.174 & $<0.001$ \\
\hline Number of bedrooms (1) & -0.334 & 0.039 & -8.602 & $<0.001$ \\
\hline Year of construction (1965) & -0.685 & 0.114 & -6.02 & $<0.001$ \\
\hline
\end{tabular}


For 'houses' and 'units', another model for each was built with categories of prison proximity as predictors to calculate the percentage change in price. The following formula was used where $(\beta)$ is the coefficient(s) of the model.

$$
\text { Percntage change of price }=\left(e^{\beta}-1\right) \times 100
$$

Change of price due to prison proximity was presented in Table 4 for both 'houses' and 'units'. Statistical analysis was performed with R statistical analysis software version 4.0.0 for Windows. The significance level was set at $\mathrm{p} \leq 0.05$ within all tests. The final model shows varying results. Property prices show reduction rates due to proximity to Pentridge from $0-400 \mathrm{~m}$ for 'houses', and from $0-600 \mathrm{~m}$ for 'units'. The percentage reduction in price for the first set of distance ranges does not show a clear pattern. Surprisingly in subsequent distances, results show that the relationship is inverted, leading to an increase in property prices, but also following an indistinctive pattern. For distance ranges $400-1400 \mathrm{~m}$ in the case of 'houses', and 600-1000m for 'units', properties show a general increase in prices. Finally, 'units' prices show a significant discounted rate in distance range 1000-1400m.

Table 4. Change of property prices due to prison proximity

\begin{tabular}{lcc}
\hline Distance to Pentridge & Percentage change-Houses & Percentage change-Units \\
\hline $\mathbf{0 - 2 0 0 m}$ & $-0.80 \%$ & $-7.41 \%$ \\
\hline $\mathbf{2 0 0 - 4 0 0 m}$ & $-3.54 \%$ & $-8.52 \%$ \\
\hline $\mathbf{4 0 0 - 6 0 0 m}$ & $0.50 \%$ & $-7.87 \%$ \\
\hline $\mathbf{6 0 0 - 8 0 0 m}$ & $10.08 \%$ & $9.09 \%$ \\
\hline $\mathbf{8 0 0 - 1 0 0 0 m}$ & $7.47 \%$ & $1.31 \%$ \\
\hline $\mathbf{1 0 0 0 - 1 4 0 0 m}$ & $18.06 \%$ & $-20.47 \%$ \\
\hline
\end{tabular}

\section{Conclusion}

Researchers of dark heritage have long argued possible effects of former gaols on their surrounding vicinity. Unlike HVOTLs, which are only perceived as a price diminution factor, the former HM Prison Pentridge in Coburg presented a complex case study for the measurement of these effects. Pentridge's picturesque architecture, its relative proximity to Melbourne's CBD, the long years that have passed after 
it was fully closed, the mixed-use districts emerging on site, and the efforts done by the site developers to eliminate any uncomfortableness associated to Pentridge did, to a noticeable extent, pardon the influence of its dark history on surrounding property prices. This research investigated the impact of Pentridge on surrounding property transactions in the period starting in January 2015 until mid-2019. The results presented show that all residential properties that are on the development site, houses which lay at distances less than $400 \mathrm{~m}$, as well as units which lay at distances less than $600 \mathrm{~m}$ to Pentridge's heritage borders, show a notable reduction in prices. Reduction in prices of close distance range suggests that visibility of the former gaol's features may still be contributing to the general discomfort of residents even after more than two decades of its decommissioning, and overweights any positive effects of the new development taking place on its land. Bond (2013), Wyman and Mothorpe (2018) and others referred to direct visual access to the factor subject of their research as a major price influencer for residential properties. This interpretation is further supported in the case of Pentridge by the idea that the distance range of 'units' is greater than 'houses'; where high-storey units in apartment buildings may still have direct visual access to Pentridge's structures over low-rise houses. On the contrary, properties lying outside that visibility range of Pentridge show an increase in prices. Such inverse impact may imply that once the direct visibility of the gaol diminishes, redevelopment on the former gaol's site appears to have created an appealing reputation for the convenience of Coburg's residents. However, the significant depreciation of 'units' prices in the most remote distance range in this study is difficult to interpret and may be due to other characteristics beyond those identified in this study.

\section{Research limitation and implications}

While there is no confirmed explanation of the varying impact of distance-ranges to Pentridge on prices of residential properties, a potential justification is the absence of one or more critical variables, e.g. condition of the property, levels of privacy, number of terraces, and air conditioning. Additionally, whether the property lies on lands that once belonged to Pentridge in history may have an impact on property prices. Other external factors that characterise the intimate neighbourhood such as the novelty of 
buildings and proximity to recreational amenities may also be affecting property prices for both houses and units. It is worth mentioning that despite 'scenic views' being among the data provided on Corelogic, it is odd that this variable did not show significant contribution to property prices. Incompleteness and inaccuracy issues of this variable as obtained from Corelogic may explain this outcome. Given the time and budget limits of this study, the data provided about properties depended only on property transaction websites, making it essential for future similar research to supplement the property variables with data collected from in-field investigations and other geo-spatial data to progress this idea further. Also, in future studies, proximity variable can be re-tested using alternative measuring mechanisms - such as the Manhattan distance (Mora-Garcia et al., 2018).

This paper examined the impact of the former HM Prison Pentridge on the surrounding residential properties sale prices from 2015 until 2019 - however, the psychological impact of the closed gaol on the sale price may not be constant since its closure. As Rellensmann (2011) and Shehata et al. (2018) presume, time can act as a healing factor. Nonetheless, the intense construction scene in the site of Pentridge coupled with the marketing campaigns since its closure are constant reminders that this is not a prison site anymore and apparently, as the results suggest, have contributed to the gradual forgetfulness of Pentridge's dark memories. Thus, this paper has manifold implications. The first implication is that future research may examine the rate of healing from gaol darkness as reflected on property prices by running statistical models on the available property sale prices on multiple time laps (e.g. of 4 to 5 years). The resulted curves showing the relationship between property prices (for the same distances) and time may indicate a healing pattern. Predicting healing trends and patterns could be a valuable tool to better assist urban designers, real estate developers, property valuers and others while dealing with places surrounding uncomfortable heritage. The second implication is the possibility of repeating the same methodology for other Australian decommissioned gaols, and even on still-in-operation $19^{\text {th }}$ Century heritage gaols in Australia such as Bathurst Correctional Centre, Goulburn Correctional Centre, and Cooma Correctional Centre all in New South Wales. Such investigations could be used as an assessment tool of the current 
level of comfortability the locals hold for these buildings, and to assess potential scenarios for reusing penal heritage and its suitability to the adjacent local real estate climate.

\section{References}

Abelson, P. \& Chung, D. (2005). The Real Story of Housing Prices in Australia from 1970 to 2003. Australian Economic Review, 38(3), 265-281.

Australian Bureau of Statistics (2019). Consumer Price Index, Australia. Retrieved June 2019 from https://www.abs.gov.au/ausstats/abs@.nsf/mf/6401.0

Bhattacharya, U., Huang, D., \& Nielsen, K.M. (2019). Spillovers in Asset Prices: The Curious Case of Haunted Houses. (HKUST IEMS Working Paper No. 2019-63). Retrieved from http://iems.ust.hk/WP

Bond, S. (2013). HVOTLs in New Zealand. In S. Bond, et al. (Eds.) Towers, turbines and transmission lines: impacts on property value (pp. 81-99). Hoboken, New Jersey: Wiley.

Broome, R. (1988). The stigma of Pentridge the view from Coburg 1850-1987. Journal of Australian Studies, 12(22), 3-18.

Bryce Raworth Pty Ltd (2016). Former Pentridge Prison: Conservation Management Plan. Retrieved July 2018 from http://pentridgecoburg.com.au/wpcontent/uploads/pdfs/Former Pentridge Prison CMP.pdf

Buxton, M. \& Scheurer, J. (2005). Expanding Urban Frontier: Urban Form in Melbourne's Growth Corridors, Melbourne, Australia: RMIT Publishing.

Callanan, J. (2013). The Effect of High Voltage Transmission Lines on Property Values: A Contingent Valuation Approach. Pacific Rim Property Research Journal, 19(2), 173-185.

Carlton, B. (2018). Penal reform, anti-carceral feminist campaigns and the politics of change in women's prisons, Victoria, Australia. Punishment \& Society, 20(3), 283-307. 
Chapman, D., Ludlum, M., Vijayan, R., Xu, W., Steelman, B., Range, D. \& Dehariya, D. (2019). Stigmatized properties and housing values: an exploratory study. Journal of Housing and the Built Environment, 34(3), 683-696.

Chappells, H. \& Shove, E. (2005). Debating the future of comfort: environmental sustainability, energy consumption and the indoor environment. Build. Res. Informat., 33(1), 32-40.

Dent, P. \& Sims, S. (2013). Risk Perception, Stigma and Behaviour. In S. Bond, et al. (Eds.) Towers, Turbines and Transmission Lines: Impacts on Property Value (pp. 27-44). Hoboken, New Jersey: Wiley.

Diao, M., Zhu, Y. \& Zhu, J. (2017). Intra-city access to inter-city transport nodes: The implications of high-speed-rail station locations for the urban development of Chinese cities. Urban Studies, 54 (10), 2249-2267.

Edney, R. (2006). Contested Narratives of Penal Knowledge: H Division Pentridge Prison and the Histories of Imprisonment. Current Issues Criminal Justice, 17(3), 362-379.

Endah, S. (2013). Impact Of Air Pollution On Property Values: A Hedonic Price Study. Jurnal Ekonomi Pembangunan: Kajian Masalah Ekonomi dan Pembangunan, 14(1), 52-65.

Galford, G. \& Peek, G.G. (2015). Locked up in lockdown: historic prisons and asylums as alternative housing with adaptive re-use challenges. Housing and Society, 42(1), 1-13.

Hui, E.C.M., Zhong, J. W. \& Yu, K. H. (2012). The impact of landscape views and storey levels on property prices. Landscape and Urban Planning, 105(1-2), 86-93.

Jackson, T.O. \& Pitts, J. (2010). The effects of electric transmission lines on property values: A literature review. Journal of Real Estate Literature, 18(2), 239-259. 
Kelly, R. B., \& Victoria. Department of Crown Lands Survey (Cartographer). (1870). Plan of Pentridge prison [cartographic material] / lithographed at the Crown Lands Office, Melbourne by R. B. Kelly [1 map on sheet 35 x $38 \mathrm{~cm}$.$] . Retrieved from http://handle.slv.vic.gov.au/10381/114242$

Kiel, K.A. \& Boyle, M.A. (2001). A Survey of House Price Hedonic Studies of the Impact of Environmental Externalities. Journal of Real Estate Literature, 9(2), 117-144.

Koster, H. R. A., \& Rouwendal, J. (2012). The Impact of Mixed Land Use on Residential Property Values. Journal of Regional Science, 52(5), 733-761.

Langston, C. (2011). Estimating the useful life of buildings (In Proceedings of the 36th Annual conference for Australasian Building Educators Association AUBEA, Gold Coast, Australia.

Lynn, P. \& Armstrong, G. (1996). From Pentonville to Pentridge: A History of Prisons in Victoria. Melbourne, Australia: State Library of Victoria.

Mann, R. 2017. Pentridge: Voices from the other side. Melbourne, VIC, AU \& London, UK: Scribe.

Mccord, J., Mccord, M., Mccluskey, W., Davis, P.T., Mcilhatton, D. \& Haran, M. (2014). Effect of public green space on residential property values in Belfast metropolitan area. Journal of Financial Management of Property and Construction, 19(2), 117-137.

Mcelveen, M.A., Brown, B.E. \& Gibbons, C.M. (2017). Natural Gas Pipelines and the Value of Nearby Homes: A Spatial Analysis. Journal of Housing Research, 26(1), 27-38.

Mora-Garcia, R., Marti-Ciriquian, P., Perez-Sanchez, R., \& Cespedes-Lopez, M. (2018). A comparative analysis of manhattan, euclidean and network distances. Why are network distances more useful to urban professionals? International Multidisciplinary Scientific GeoConference Surveying Geology and Mining Ecology Management, SGEM, 18(2), 3-10. 
Moreland City Council. (n.d.). History of Pentridge Prison. Retrieved March 2019 from Moreland City Council's Website https://www.moreland.vic.gov.au/about-moreland/history-ofmoreland/history-pentridge.html

Mothorpe, C.C. \& Wyman, D.M. (2017). The appraisal of residential water view properties. The Appraisal Journal, 85(2), 130-141.

Narwold, A.J. (2008). Estimating the value of the historical designation externality. International Journal of Housing Markets and Analysis, 1(3), 288-295.

Nicholls, S. \& Crompton, J.L. (2018). The contribution of scenic views of, and proximity to, lakes and reservoirs to property values. Lakes \& Reservoirs: Research \& Management, 23(1), 63-78.

Osborne, D. (2015). Pentridge: Behind the Bluestone Walls. South of Melbourne, Australia: echo publishing, part of Bonnier Publishing Group.

Pope, J.C. (2008). Fear of crime and housing prices: Household reactions to sex offender registries. Journal of Urban Economics, 64(3), 601-614.

Powell, A. \& Sanguinetti, P. (2010). Measuring Quality of Life in Latin America's Urban Neighborhoods: A Summary of Results from the City Case Studies. In E. Lora, et al. (Eds.) The quality of life in Latin American cities markets and perception (pp. 47-75). Washington, D.C.: World Bank.

Pratt, J. (2003). The disappearance of the prison: An episode in the 'civilising process'. In Isolation: Places and Practices of Exclusion (pp. 19-36): Routledge Taylor \& Francis Group.

Priestley, T. \& Ignelzi, P. C. (1989). A Methodology for Assessing Transmission Line Impacts in Residential Communities. Washington, D.C.:Edison Electric Institutem. 
Rellensmann, L. (2011). Converting Uncomfortable Heritage Inner-city Bunkers: From a War Site to an Urban Scene Spot. In S. Merrill \& L. Schmidt (Eds.), A Reader in Uncomfortable Heritage and Dark Tourism (pp. 216-231). Germany: BTU Cottbus.

R Core Team. (2019). R: A language and environment for statistical computing. Retrieved from https://www.R-project.org/

RP Data Pty Ltd. (2017). Residential Property Index Series. Retrieved April 2020 from www.corelogic.com.au/sites/default/files/2017-09/CoreLogicHPISeriesMethodologyAug2017.pdf

Sah, V., Conroy, S.J. \& Narwold, A. (2016). Estimating School Proximity Effects on Housing Prices: the Importance of Robust Spatial Controls in Hedonic Estimations. Journal Of Real Estate Finance And Economics, 53(1), 50-76.

Sandler, D. (2011). Counterpreservation: Decrepitude and Memory in Post-Unification Berlin. Third Text, 25(6), 687-697.

Shayher Properties (2014). Pentridge Coburg 2014 Design Guidelines and Masterplan, Shayher Group, Melbourne, VIC.

Shayher Properties Pty Ltd (n.d.). Living at Pentridge. Retrieved August 2018 from http://pentridgecoburg.com.au/apartments/

Shehata, W., Langston, C. \& Sarvimäki, M. (2018, December). From Uncomfortable to Comfortable: The Adaptive Reuse of Australian Gaols. (Paper presented at the International Heritage and Cultural Conservation Conference, Kuching, Sarawak, Malaysia. Retrieved 2 March 2019 from https://research.bond.edu.au/en/publications/from-uncomfortable-to-comfortable-the-adaptivereuse-of-australia 
Shin, J.H. (2016). Toward a theory of environmental satisfaction and human comfort: A process-oriented and contextually sensitive theoretical framework. Journal of Environmental Psychology, 45, 1121.

Simons, R. A. \& Saginor, J. D. (2006). A meta-analysis of the effect of environmental contamination and positive amenities on residential real estate values. Real Estate Research, 28(1), 71-104.

Simons, R. A., Seo, Y. \& Rosenfeld, P. (2015). Modeling the Effects of Refinery Emissions on Residential Property Values. Journal Of Real Estate Research, 37(3), 321-342.

Smith, J. (2011). Losing the plot: Archaeological investigations of prisoner burials at the Old Melbourne Gaol and Pentridge Prison. Provenance, (10), 62-72.

State Government Of Victoria. (2019). Property prices: Annual and quarterly property sales statistics from Valuer-General Victoria. Environment, Land, Water, and Planning. Retrieved September 2019 from https://www.propertyandlandtitles.vic.gov.au/property-information/property-prices

Swinburne Institute for Social Research (2000). Housing Past. Housing Futures, Melbourne, Australia.

Victoria State Government (2019). Planning Maps Online. Retrieved 3 July 2019 from https://mapshare.vic.gov.au/vicplan/

Whipple, R. T. M. (2006). Property valuation and analysis. Pyrmont, N.S.W: Lawbook.

Wilson, J. Z. (2004). Dark tourism and the celebrity prisoner: Front and back regions in representations of an Australian historical prison. Journal of Australian Studies, 28(82), 1-13.

Wilson, J. Z. (2005). Representing Pentridge: The loss of narrative diversity in the populist interpretation of a former total institution. Australian Historical Studies, 36(125), 113-133.

Wyman, D., \& Mothorpe, C. (2018). The pricing of power lines: A geospatial approach to measuring residential property values. Journal of Real Estate Research, 40(1), 121-154. 
Wyman, D., Dent, P. \& Sims, S. (2013). Methods. In S. Bond, et al. (Eds.), Towers, Turbines and

Transmission Lines: Impacts on Property Value (pp. 11-25). Hoboken, New Jersey: Wiley. 